DOI: $10.51480 / 1899-5101.14 .1(28) .4$

\title{
Zelensky's Image in the Russian and Ukrainian News: Presidential Campaign 2019 in Ukraine
}

\author{
Katrin Dkhair \\ 0000-0003-1956-1353 \\ Higher School of Economics, National Research University in Saint Petersburg, Russia

\section{Polina Klochko} \\ iD 0000-0002-3812-4645 \\ Higher School of Economics, National Research University in Saint Petersburg, Russia
}

\begin{abstract}
The work explores the portrayal of the sixth president of Ukraine, Volodymyr Zelensky, in Russian and Ukrainian media sources during the pre-electoral campaign in 2019. The study used network analysis, n-grams' generation, and LDA-based topic modeling. The study reveals that Russia's media focused on Zelensky as a media personality, while Ukrainian sources paid attention to the portrayal of a novel popular politician. The target audience of the candidate's campaign was the Russian-speaking population of Ukraine. Media in Ukraine's native language were more inclined to mention elections, the role of the other candidate Petro Poroshenko and the nationalist mood, while defining Zelensky as just an ordinary candidate in an electoral race. The article is based on academic resources concerning the history of the development of political and media contexts in Ukraine, paying particular attention to agenda-setting, framing and priming techniques, and the personality of Volodymyr Zelensky.
\end{abstract}

KEYWORDS: Volodymyr Zelensky, discourse, media, network analysis, topic modeling.

\section{INTRODUCTION}

Contemporary Ukraine is one of the former socialist republics that proclaimed independence in 1991, the last year of the Soviet Union's existence. As in many post-Soviet states, clientelism, patronage and corruption (Spirova, 2008) continued in conjunction with state capture, which hindered the newly independent nation's transition towards liberal democracy. While benefitting from the cessation of Communism's overarching doctrine, Ukraine became trapped in the hybridity of own institutions (Matsiyevsky, 2018: 351). 
Rigged elections often became an issue in public agenda, provoking public manifestations (Beissinger, 2011: 25). The first demonstrations occurred in 2004 during the transition of power from the second Ukrainian president Leonid Kuchma to his successor Victor Yanukovych and transformed into the Orange Revolution. Due to marked voting irregularities, such as "ballot-stuffing", falsification of the vote count, or denial of observers' access to the polling stations (Pifer, 2007: 29), a popular struggle for fair elections turned into protests on Ukraine's most famous square - Maidan Nezalezhnosti. Therefore, the third electoral round, monitored by international observers, brought to power Victor Yushchenko (Karatnysky, 2005: 36-41). His political views made a significant contribution to the country's orientation towards integration in the European Union (Kuzio, 2005: 35).

However, the Euromaidan Revolution, called in the Ukrainian discourse the "Revolution of Dignity", escalated not as a result of electoral fraud. In November 2013, the Ukrainian president Victor Yanukovych made a unilateral decision to stop, at the last moment, the European integration process, favoring negotiations with the Russian Federation. The abrupt cessation of talks finalizing the EU's Association Agreement, rising levels of corruption, and the violent suppression of public demonstrations (Shveda \& Park, 2016: 90) eroded the legitimacy of Yanukovych's regime. Desire to join European civilizational path and radicalization (Baysha, 2019: 123, 133) took precedence over outstanding linguistic and ethnic issues and merged into the new Maidan protests. Nevertheless, the expected urgent presidential elections did not occur because on February 22 2014, President Yanukovych, fearing for his personal safety, fled Ukraine for Russia. The Maidan Revolution became a reason for territorial disintegration.

Within such a context, the first elections that were supposed to happen under constitutionally defined terms after the Euromaidan events were of huge interest internally and externally. The new president had to be fairly elected and to reflect European values. Furthermore, he had to be distanced from traditional Ukrainian politicians. The popular Ukrainian news TV channel described traditional politicians as being corrupt, nepotic enforcers of censorship, and supplemented the typical image of political outsider by mentioning pre-electoral tactics of "dirty technologies, [making] mutual accusations and ordinary promises” (TSN.ua, 2019).

The aim of the paper is to see how the figure of the candidate who became the sixth Ukrainian President was presented by Russian and Ukrainian news. The presidential elections took place in March-April 2019, so the analysis of Zelensky's political figure remains insufficient. However, some of the articles are worth considering. For instance, Korosteleva and Samokhvalov depicted Volodymyr Zelensky, as a rival of the Ukrainian establishment, who paved the way to electoral success through the TV show "Servant of the People" (Korosteleva \& Samokhvalov, 2019: 2). Apart from television aspect, Mashtaler singles out 
Zelensky's skillful use of media and digital technologies, in particular social networks, which define his victory (Mashtaler, 2019:142-145).

Therefore, Zelensky turned to traditional and virtual media resources in order to create favorable personal image and attract the electorate vote. The strategy proved successful: in the first round Zelensky received 30\% of the votes, compared to his closest rival, the incumbent Petro Poroshenko with a share of 16\% (Korosteleva \& Samokhvalov, 2019: 1).

As the elections are now history, it would be interesting to identify the narratives operating in Ukraine, at the time. However, we did not want to limit the scope of research by solely analyzing Ukraine's media and decided to evaluate the aforementioned presidential candidate's representation in the Russian media as a comparison. It can subsequently serve as a basis for evaluating international relations between the two former "brother countries".

The research question of the study can be formulated in the following way: "How did Ukrainian and Russian journalists represent Zelensky during pre-electoral campaign?". In other words, we wanted to see whether the media framed Volodymyr Zelensky as a competitive novel politician, or as a businessman and comedian who decided to engage in politics.

\section{VOLODYMYR ZELENSKY AND UKRAINIAN POLITICS}

According to Freedom House, Ukraine is a partly free state (Ukraine Country Report, 2020). By contrast, Russia is not a free state (Russia Country Report, 2020). A 2020 report indicates that modern Ukraine is actively reforming, even though all-encompassing democratization is impossible due to the inability to control the Crimea and self-proclaimed Republics in the East of the country. Ukraine's constitutionally defined borders are in a suspended state due to the Crimean Referendum of 2014, and the ongoing conflict in eastern Ukraine, called in the official Ukrainian discourse the "hybrid war" (Kofman \& Rojansky, 2015: 2). According to Article 73 of the Ukrainian Constitution, only all-Ukrainian Referendum can decide "changes in Ukrainian territory" (Constitution of Ukraine, 2020). Hence the Crimean-led referendum, assisted by Russia, as well as 2014 Donetsk and Luhansk unilateral referenda on independence were led in violation of Ukrainian law. The Freedom House report claims that state disintegration led to a limited circulation of "culture products" in the Russian language within the country and to a restricted accessibility of Russian media outlets (Ukraine Country Report, 2020). In the Russian Federation, the traditional media outlets, such as television, radio, and the print press, are largely state controlled, with opposition journalists being intimidated, harassed, or imprisoned (Russia Country Report, 2020). 
A core aspect of Ukraine's media environment since independence and the adoption of legislation legalizing private media ownership in the 1990s is the privatization of major media outlets (Ryabinska, 2011: 5). Thus, large media outlets are controlled by Ukrainian oligarchs (Szostek, 2014). The ongoing interrelationship between the media and citizens' political attitudes fits the ideas of traditional mass persuasion concepts. According to the Ukrainian civic organization "Detector.media", Ukrainian television remains the most popular source of information acquisition, attracting attention of $74 \%$ of the respondents (Detector.media, 2019). Agenda setting and framing seem to be powerful tools for stimulating preferred electoral results primarily due to the heterogeneity of media space and developed political opposition. The difference between the two notions is essentially that agenda setting signals the importance of certain events over the other (Coleman, McCombs, Shaw \& Weaver, 2009: 147), whereas framing approach aims at defining the "frames", particular representations of the events (Tversky \& Kahneman, 1981: 453). Another tool, which is worth mentioning for a better understanding of Ukrainian media space, is priming, which is a reflection about previously absorbed information through "intuitive shortcuts" (Krosnick \& Kinder, 1990: 499). Priming can refer to already existing viewpoints of an issue circulating in society. Thus, the TV show "Servant of the People" not simply paved the way for Zelensky's presidential campaign, but primed his success (Korosteleva and Samokhvalov, 2019: 2). Consequently, competition within a wide range of simultaneous hegemonic contestations (Laclau \& Mouffe, 2001) stimulates candidates to conduct hidden agitation through the public mass media. The final goal of politicians is to collect as many votes as possible by making a voter believe that it was their deliberation, not influenced by manipulation techniques (Seceleanu, 2009: 269-270).

So, what is Zelensky's place in the media struggle during the pre-electoral campaign of 2019? The sixth Ukrainian president does not represent a Ukrainian politician in the traditional sense. He is a complete newcomer to politics. Zelensky is an example of an individual, whose success is wholly meritorious. $\mathrm{He}$ is a descendant of a family of intellectuals (Kots, 2019), who became famous for participating in KVN in the performance group "Kvartal 95" (Ray, 2019). $\mathrm{KVN}$ is a "Club of the Merry and Resourceful" that is popular comedy TV show in post-Soviet space (Evans, 2019). Nowadays, Zelensky's entertainment group Kvartal 95 Studio is a large entertainment studio, which claims on its website to be the largest in Central and Eastern Europe. Surprisingly, such a distancing from politics became Zelensky's major advantage and allowed him to become a populist leader. By definition, populism is a "mode of identification available to any political actor operating in a discursive field, in which the notion of sovereignty of the people and the conflict between the powerful and powerless are core elements of political imaginary" (Panizza, 2005: 4). 
The post-independence political apparatus had by 2018 lost the trust of the people generating a crisis of representation. Ukrainian politics needed new faces, who could suit modern demands. In contrast to Zelensky, his major political rival in 2019 was the incumbent President Petro Poroshenko, who had gained access to power in the aftermath of the Euromaidan of 2013/2014. Poroshenko can be compared to Viktor Yushchenko, as they both acquired supporters during protests. In practice, Poroshenko who represented the 'old guard' of Ukrainian politics, inherited the political strategies of Yushchenko. Prior to the 2004 presidential election, Petro Poroshenko became one of the leaders of Viktor Yushchenko's team. Poroshenko was one of the faces of the protests during the Orange Revolution, right after Yushchenko and Yulia Tymoshenko (Chervonenko, 2014).

Despite playing a populist card in 2014, Poroshenko's public support began to steadily declining, and by the time of 2019 electoral campaign, his position was unstable. Poroshenko's major policy failures were his inability to end Donbass conflict and to get rid of corruption (Iwański, 2018: 1-2). The survey of the Ukrainian sociological group "Rating" in May-June 2019 revealed that "more than $80 \%$ " of the respondents were dissatisfied with Poroshenko's presidency (Rating, 2019).

It seems that Volodymyr Zelensky was that needed new face in politics. Zelensky was a famous Ukrainian comedian and actor who restored a direct link between politics and the electorate through the success of the television series "Servant of the People", where he played a history teacher. Zelensky's character became a president and by the end of the third season solved all the state's problems. By naming a political party after the TV series, Zelensky primed own success, referring to the achievements of his character in the show. The most supported party in the election was Zelensky's "Servant of the People" (Ibid.) with Zelensky gaining $72 \%$ of the vote. In the previously cited "Rating" survey, "the vast majority" of Ukrainians (88\%) said that they expected a radical change for the better (Rating, 2019). By contrast to Poroshenko's approval rates, Zelensky's first months in the presidency were welcomed by half of the respondents, while only $11 \%$ opposed his activities (Ibid.). Consequently, Zelensky's previous inactivity in Ukrainian politics, combined with a fruitful media priming resulted in the high electorate support from the outset. 


\section{METHODOLOGY}

Our sample includes internet news reports by Ukrainian and Russian journalists in the period from January 1,2019, the outset of the pre-electoral race, till March 30, 2019, the official Day of Silence. . We limited our research to the first round of voting, as within this time span media activity concerning the election had unfolded. Texts were retrieved from the "electronic archive and data base of mass media" "Public.ru" (Public.ru, 2020), which includes publications of Ukrainian and Russian journalists in Russian, as well as those made by Ukrainian journalists in Ukrainian. Since texts can be retrieved from "Public. ru" only in limited quantities (no more than 1000 at a time), we collected data in several stages.

In order to understand Zelensky's portrayal in the media, we commenced at discovering a general field of discursivity in Ukraine, or which contrasting narratives operated within the country (Laclau \& Mouffe, 2001: 111). After lemmatizing texts using mystem.exe application, we removed unnecessary braces (brackets, parentheses) and numbers, and filtered out stop words. Due to the insufficiency of Snowball stopwords list (Snowball, 2021) for the Ukrainian language, many words were filtered and lemmatized manually. After conducting these procedures, we coded the resulting collection of words and visualized the 14 most used words (unigrams) ${ }^{2}$ in the samples of Russia's media, Ukraine's Russianlanguage media, and Ukraine's native-language media. The next step was the construction of n-grams (see the seminal paper which gave rise to information theory by Shannon, 1948). The network depicted journalists' collocations, used for characterizing Volodymyr Zelensky. Visualizations were adjusted to the sample size in order to preserve images from word's overlap.

All these operations and those that follow were applied to nine text files uploaded from public.ru - six from Russian media in Russian (5352 publications), two files from Ukrainian media in the Russian-language (1359 publications), and one file from Ukrainian media in the native-language (171 publications) using the statistical computing program $\mathrm{R}$ (R Core Team, 2020). The next step involved applying LDA-based topic modeling to categorize the files. The main idea of this approach is that each document is represented a "random mixture over latent

1 Ukrainian law does not permit political campaigning to occur on the day before the electorate cast their votes. This is known as the Day of Silence.

$2 \mathrm{~N}$-gram modeling involves patterns of single words (unigrams) each with its own meaning that appear next-to - each-other in a sentence. Thus, in the opening seven words of this example "N-gram modeling involves patterns of single words" there are seven unigrams; six bigrams [N-gram modeling, modeling involves, involves patterns etc.; five trigrams [N-gram modeling involves, modeling involves patterns etc.] and so on up to decigrams of 10 words. 
topics" (Yau, Porter, Newman \& Suominen, 2014: 6). Every topic is characterized by the distribution over words. After identifying the words' distribution by topic, it is often possible to assign a name or description to the sequences manually (Yau et al., 2014: 10). Although this method has its limitations, such as the complexity of reproducing results and overall subjectivity, we decided to compare an obtained output with the results in R (R Core Team, 2020).

Using a topic modeling tool, 15 topics were identified in the discourses in Russian and Ukrainian media. Later, the topics were supplemented with descriptions for revealing trends in the media sources. The description threshold was 10 words per topic, because this quantity is sufficient for knowing the meaning but not too great for making judgements. During the interpretation process, a problem in topic definition arose, as some of the topics contained specific dates or common words. So, we used only content type topics, relevant for the study.

One important issue concerned the whole research procedure. In order to make our findings more accessible to the scholarly community, we have manually translated the output into English. The rigorousness of the procedure guaranteed, to a degree, that the initial meaning would not be distorted. We did our best to adjust proper names to the translation rules of both the Russian and the Ukrainian languages. Therefore, Vladimir is a direct translation of a Russian name, while Volodymyr is its alternative in Ukrainian. The only exception was Petro Poroshenko, a unique political figure in the context of the 2019 electoral race. We suspected that the change in his name might provoke unnecessary confusion.

\section{FINDINGS}

Our first objective was to get an insight on the general information flows, formed by the three beforementioned categories of journalists. Further, we investigated Zelensky's portrayal specifically. Figures 1, 2 and 3 illustrate the most used 14 unigrams in the collated texts. 
Figure 1. Unigrams in Russia's media discourse

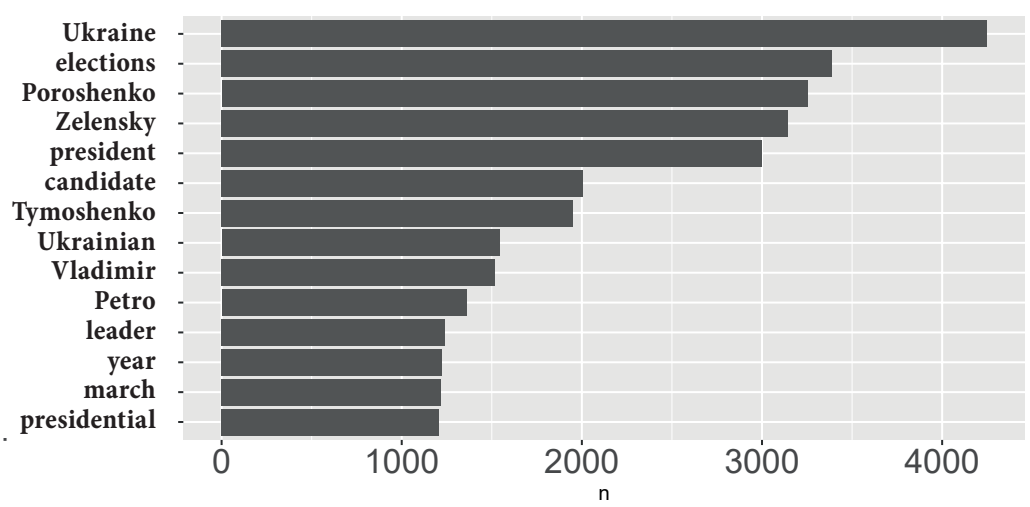

Source: Authors

Figure 2. Unigrams in Ukraine's Russian-language media discourse

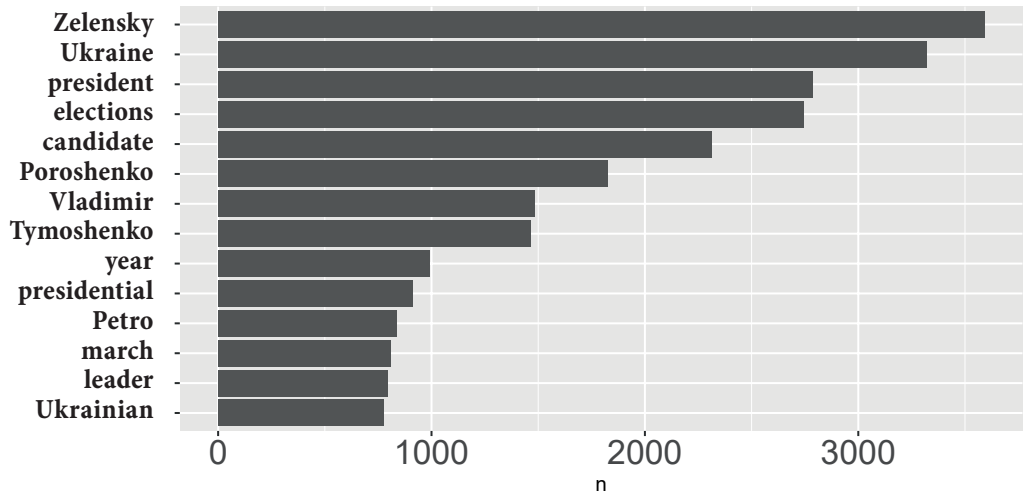

Source: Authors

Figure 3. Unigrams in Ukraine's native-language media discourse

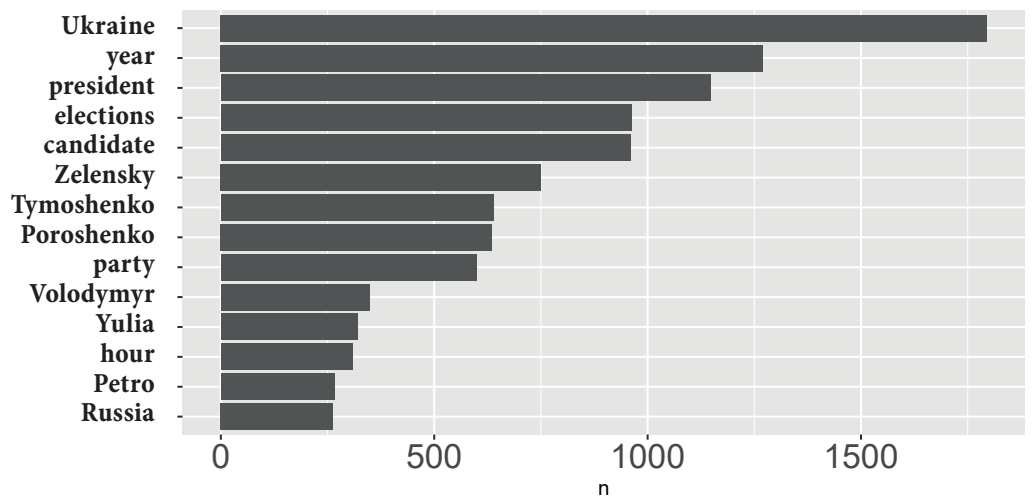

Source: Authors 
It is noticeable that there are more similarities between Russia's media (Figure 1) and Ukraine's native-language media (Figure 3). The most cited word was "Ukraine", which indicates that both media were inclined to depict an electoral process in a general way. The focus of Russia's media and journalists was the contest between Zelensky and Poroshenko. For Ukraine's native-language reporters, the political struggle between Poroshenko and Tymoshenko was more of a routine (as shown by the same frequency of appearances, see Figure 3), whereas Zelensky was slightly more interesting for the same audience. Even though the size of samples is not equal, Ukraine's Russianlanguage media (Figure 2) had the largest frequency of mentioning Volodymyr Zelensky, so the surname of the sixth president of Ukraine occupied the first rank. Zelensky was referred to more than 3500 times. For identifying how Zelensky was portrayed in the text samples, we also looked for collocations, where Zelensky was one half of a bigram.

The constructed networks demonstrate that the samples of Russia's media and Ukraine's Russian-language media shared the same vision of the candidate, describing him mostly as a "comedian" and "showman". By contrast, Ukraine's native language sample lacks any characteristics, having a more detailed and coherent network around the node "Petro Poroshenko". Nevertheless, the latter is only treated as an "incumbent president", which is a generalized and unspecific characteristic. The interesting aspect is the journalists' interest in the electoral support of Poroshenko and Zelensky. For Russia's media, the repeated check of Poroshenko's popular support was more significant, whereas in the Ukraine's Russian-language media the same collocations were constructed around the surname of Zelensky. Therefore, Russia's journalists were curious to which extent neighboring Ukraine favored sustaining of status quo, while Ukraine's Russian-language journalists wanted to estimate the prospects of Zelensky.

Investigating topics in three discourses through topic modeling, we obtained similar results. In the discourse of Russia's media (Table 1), journalists were interested in depicting the confrontation between Poroshenko and Zelensky. The latter was framed in accordance with his background. Zelensky was presented as a comedian and media person. It is worth considering the focus on changing the status quo in Ukraine. Journalists questioned further relations with Russia after the presidential change over, which is consistent with results mentioned above. 
Table 1. Topics in Discourse of Russia's media

\begin{tabular}{c|l|l}
\hline No. & \multicolumn{1}{c}{ Description } & \multicolumn{1}{c}{ Topic- Keywords } \\
\hline 1 & $\begin{array}{l}\text { Confrontation between Zelensky } \\
\text { and Poroshenko (ratings) }\end{array}$ & $\begin{array}{l}\text { Zelensky Poroshenko Ukraine rating president } \\
\text { campaign candidate last election policy }\end{array}$ \\
\hline 2 & Election fraud and observations & $\begin{array}{l}\text { Russia tour Tymoshenko falsification observer } \\
\text { institute maidan Petro source debate }\end{array}$ \\
\hline 3 & $\begin{array}{l}\text { Background of Zelensky } \\
\text { (comic, showman) }\end{array}$ & $\begin{array}{l}\text { Zelensky showman comic president new } \\
\text { party run political TV channel team }\end{array}$ \\
\hline 5 & $\begin{array}{l}\text { Competition between } \\
\text { candidates (opinion polls) }\end{array}$ & $\begin{array}{l}\text { Ukraine Tymoshenko candidate survey showman } \\
\text { Poroshenko result race opinion chance }\end{array}$ \\
\hline 6 & $\begin{array}{l}\text { Who will be the leader in the } \\
\text { upcoming elections? }\end{array}$ & $\begin{array}{l}\text { document registrations propose campaign intention } \\
\text { business term negotiation run inform }\end{array}$ \\
\hline 7 & $\begin{array}{l}\text { Tymoshenko and Poroshenko } \\
\text { as candidates }\end{array}$ & $\begin{array}{l}\text { president Vladimir election Ukraine leader } \\
\text { pre-election new acting state victory }\end{array}$ \\
\hline 8 & $\begin{array}{l}\text { Russian-Ukrainian relations } \\
\text { (Crimea, selective ban on the } \\
\text { entry of artists in the country) }\end{array}$ & $\begin{array}{l}\text { Yulia party election March leader Ukraine } \\
\text { Poroshenko race batkivshchyna candidate }\end{array}$ \\
\hline $\begin{array}{l}\text { Boyko citizen Putin Okhlobystin Moscow } \\
\text { Porechenkov Kyiv participation Crimea lead }\end{array}$
\end{tabular}

Source: Authors

Regarding the reports of Ukrainian journalists targeting Russian-speaking population (Table 2), Zelensky was the center of attention. Some topics represent the stories about the presidential candidate. They stress his participation in the famous show "Kvartal 95" and the TV series "Servant of the People". Moreover, the vision of the new leader in Ukrainian politics is strongly emphasized. The role of the electoral process itself is also reflected. Therefore, the correlation between the discourses of Russia's and Ukraine's Russian-language media is remarkable.

In a relatively small part of the messages in Ukraine's native-language (Table 3), the description of topics was difficult due to language features. Journalists tried to devise the most provocative headlines and texts using epithets, metaphors, and other rhetorical devices, for which reason only four topics proved to be relevant. The difference of the sample from the other two (Tables 1 and 2) is only the larger representation of Tymoshenko and Poroshenko. There were no separate topics found on Zelensky. We witnessed just reminders of the upcoming elections, in which Zelensky was considered as one of the candidates. Ukrainian national values, valorization of independence, and relations with other countries were also highlighted. The components turned out to be useful for framing the news about electoral process. Significant attention was devoted to contrasting Ukrainian and Russian electoral systems. 
Table 2. Topics in the Discourse of Ukraine's Russian-language media

\begin{tabular}{c|l|l}
\hline No. & \multicolumn{1}{|c}{ Description } & \multicolumn{1}{c}{ Topic - Keywords } \\
\hline 1 & Zelensky vs Poroshenko & $\begin{array}{l}\text { Petro Vladimir candidate leader first place } \\
\text { team position support region }\end{array}$ \\
\hline 2 & March 31 election reminder & $\begin{array}{l}\text { president Ukraine candidate election state } \\
\text { selective Ukrainian remind March people }\end{array}$ \\
\hline 3 & $\begin{array}{l}\text { International coverage of events } \\
\text { in Ukraine (Crimea) }\end{array}$ & $\begin{array}{l}\text { choose security organization manager department } \\
\text { Macron south European annexation hiring }\end{array}$ \\
\hline 4 & $\begin{array}{l}\text { Observation of the } \\
\text { electoral process }\end{array}$ & $\begin{array}{l}\text { March Yulia Poroshenko observer state } \\
\text { falsification reform article exit tour }\end{array}$ \\
\hline 5 & $\begin{array}{l}\text { Nomination of Zelensky } \\
\text { as a candidate (reference to the } \\
\text { show “Kvartal 95" and TV series } \\
\text { "Servant of the People") }\end{array}$ & $\begin{array}{l}\text { registration run submit advance nominate } \\
\text { register servant appeal leader kvartal }\end{array}$ \\
\hline 6 & $\begin{array}{l}\text { Conducting opinion polls } \\
\text { (Poroshenko and Tymoshenko) }\end{array}$ & $\begin{array}{l}\text { Tymoshenko survey Poroshenko result research } \\
\text { ask side sociological dialogue civil }\end{array}$ \\
\hline 7 & $\begin{array}{l}\text { Statements of Zelensky, his story } \\
\text { Zelensky Vladimir declare party Ukrainian } \\
\text { kvartal state life comic famous }\end{array}$ \\
\hline 8 & $\begin{array}{l}\text { Features of the election process } \\
\text { tour vote ballot power get opinion data news support district }\end{array}$ \\
\hline
\end{tabular}

Source: Authors

Table 3. Topics in the Discourse of Ukraine's native language media

\begin{tabular}{c|c|c}
\hline No. & Description & Topic \\
\hline 1 & $\begin{array}{c}\text { The choice between Poroshenko } \\
\text { and Zelensky }\end{array}$ & $\begin{array}{c}\text { president Zelensky candidate Ukraine } \\
\text { choice time Poroshenko }\end{array}$ \\
\hline 2 & Tymoshenko and Zelensky & Tymoshenko Volodymyr Ukraine party president ala Russia \\
\hline 3 & The role of Russia & new pro-Russian opposition program state scandal voter \\
\hline 4 & Interests and values of Ukraine & $\begin{array}{c}\text { people state independence daughter } \\
\text { reliance interest ambition }\end{array}$ \\
\hline
\end{tabular}

Source: Authors

To sum up, our research became an illustration of the 2019 presidential race. The study revealed existing differences in news coverage, as journalists' reports targeted the two language groups of Ukraine's population - Russian and Ukrainian speaking. Such a contrast demonstrated internal societal division and heterogeneity. For this reason, journalists framed and primed Zelensky's figure in dissimilar ways, pursing contrasted goals. For Ukraine's native language media, Zelensky was just a comedian who decided to enter politics, whereas for Ukraine's Russian-language journalists, Zelensky was a curious political alternative, a new face in the political arena. 


\section{CONCLUSIONS}

In conclusion, providing the research and implementing the n-grams' generation, the network analysis, and topic modeling (LDA), the various representations of Volodymyr Zelensky in information resources were revealed. The mixed method allowed us to compare the results and make more trustworthy inferences. We found out that Russian-speaking Ukrainian journalists were actively involved in promoting Zelensky's candidature (unigram analysis) and evaluating his electoral prospects (bigram analysis).

Unexpectedly, the representation of Zelensky in Russia's and Ukraine's Russianlanguage media shared a lot of similarities. Journalists focused on the past life of a new politician. However, Russia's media were more interested in the on-going state of Ukrainian politics, prospects for disruption of the status quo, as well as in the confrontation between the incumbent president, Poroshenko, and the political newcomer, Volodymyr Zelensky. At the same time, Russia's and Ukraine's native-language samples were compatible in terms of the most used words, as their major focus was the general Ukrainian electoral process. Results of Ukraine's Russian-language sample confirmed our expectations about the target audience of Zelensky's campaign. Sources in Ukraine's native-language had their own peculiarities with a noticeable focus on the nationalist mood in the country. There was no emphasis on depicting Zelensky's figure. Ukraine's native-language journalists mostly aimed at forming the image of Poroshenko. Therefore, the heterogeneity of Ukrainian society allowed journalists to differentially depict Volodymyr Zelensky, depending on their political affiliation. Such contesting representations allowed the Ukrainian people to form a particular image of the candidates in the political race.

While conducting our research, we thought of calculating the log odds ratio with the aim of measuring the differences in frequencies of using the word "Zelensky" in the Russian-language samples of Russia and the Ukraine. However, none of the results had any statistical significance. Moreover, the topic modelling method implies a degree of subjectivity, as the topic's interpretation is the responsibility of the researcher. Another significant limitation concerns peculiarities of Ukraine's native-language sample, and necessitated manual corrections. 


\section{REFERENCES}

Baysha, O. (2019). Miscommunicating social change: Lessons from Russia and Ukraine. Lexington Books. Beissinger, M. (2011). Mechanisms of Maidan: the structure of contingency in the making of the Orange Revolution. Mobilization: An International Quarterly, 16(1): 25-43.

Chervonenko, V. (2014, May 28). P'yatyy prezydent: shlyakh Poroshenka do posady [Fifth President, Poroshenko Path to the Office]. BBC Ukrayina. Retrieved February 17, 2021 from https://www.bbc. com/ukrainian/politics/2014/05/140528_poroshenko_biography_profile_vc

Coleman, R., McCombs, M., Shaw, D., \& Weaver, D. (2009). Agenda setting. The Handbook of Journalism Studies. Routledge Handbooks Online.

Detector. media (2019, March 21). Dzherela Informatsiyi, Mediahramotnist i Rosiyska Propahanda: Rezultaty Vseukrayinskoho Opytuvannya Hromadskoyi Dumky [Джерела Інформації, Медіаграмотність і Російська Пропаганда: Результати Всеукраїнського Опитування Громадської Думки]. Detector.media. Retrieved March 4, 2021. https://detector.media/infospace/ article/164308/2019-03-21-dzherela-informatsii-mediagramotnist-i-rosiiska-propaganda-rezultati-vseukrainskogo-opituvannya-gromadskoi-dumki/.

Evans, C. (2019). How Soviet Game Shows Explain the Popularity of Ukraine's New President (May 13). The Washington Post. Retrieved March 1, 2021 from https://www.washingtonpost.com/outlook/2019/05/13/how-soviet-game-shows-explain-popularity-ukraines-new-president/.

Freedom House (2020). Russia Country Report. Retrieved March 4, 2021 from https://freedomhouse. org/country/russia/freedom-world/2020.

Freedom House (2020). Ukraine Country Report. Retrieved March 4, 2021 from https://freedomhouse. org/country/ukraine/freedom-world/2020.

Iwański, T. (2018). Poroshenko Stands Alone. Ukraine Politics in a Pre-Election Year. Centre for Eastern Studies, (269): 1-8.

Karatnycky, A. (2005). Ukraine's Orange Revolution. Foreign Affairs, 84: 35-52.

Kofman, M., \& Rojansky, M. (2015). A Closer Look at Russia's' Hybrid War'. Woodrow Wilson International Center for Scholars, (7): 1-8.

Korosteleva, E. \& Samokhvalov, V. (2019, April). A Comedian, A President, and A Prime Minister: the 2019 presidential election in Ukraine. In LSE Dahrendorf Forum: 1-2.

Kots, A. (2019, April 25). Volodymyr Zelensky's Biography: How the Stand-Up Comedian Became the President of the Ukraine. South Front. Retrieved February 17, 2021 from https://southfront.org/volodymyr-zelenskys-biography-how-the-stand-up-comedian-became-the-president-of-the-ukraine/.

Krosnick, J. A., \& Kinder, D. R. (1990). Altering the Foundations of Support for the President Through Priming. The American Political Science Review, 84(2): 497-512.

Kuzio, T. (2005). From Kuchma to Yushchenko Ukraine's 2004 Presidential Elections and the Orange Revolution. Problems of Post-Communism, 52(2): 29-44. 
Laclau, E., \& Mouffe C. (2001). Hegemony and Socialist Strategy: towards a Radical Democratic Politics (2nd ed.). Verso.

Mashtaler, O. (2019) The 2019 Presidential Election in Ukraine: Populism, the Influence of the Media, and the Victory of the Virtual Candidate. In C. Kohl, B. Christophe, H. Liebau, \& A. Saupe (Eds.), The Politics of Authenticity and Populist Discourses: Media and Education in Brazil, India and Ukraine. Palgrave Macmillan.

Matsiyevsky, Y. (2018). Revolution without Regime Change: The Evidence from the Post-Euromaidan Ukraine. Communist and Post-Communist Studies, 51(4): 349-59.

McCombs, M. (2005). A Look at Agenda-setting: Past, Present and Future. Journalism Studies, 6 (4): 543-557.

Panizza, F. E. (2005). Populism and the Mirror of Democracy. Verso.

Pifer, S. (2007). European Mediators and Ukraine's Orange Revolution. Problems of Post-Communism, 54(6): 28-42.

Public.ru. Elektronnaya Biblioteka Periodiki i Monitoring SMI [Electronic Library of Periodicals and Media Monitoring]. Public.ru. Retrieved February 17, 2021 from https://www.public.ru/lib.

Rating (2019). Monitoring of electoral moods of Ukrainians (29 May - 3 June, 2019). Rating Group. Retrieved February 17, 2021 from http://ratinggroup.ua/en/research/ukraine/monitoring_elektoralnyh_nastroeniy_ukraincev_29_maya_3_iyunya_2019_goda.html.

Ray, M. (2019, September 27). Volodymyr Zelensky. Encyclopcedia Britannica. Retrieved February 17, 2021 from https://www.britannica.com/biography/Volodymyr-Zelensky.

$\mathrm{R}$ Core Team (2020). R: A language and environment for statistical computing. R Foundation for Statistical Computing, Vienna, Austria. URL https://www.R-project.org/.

Ryabinska, N. (2011). The Media Market and Media Ownership in Post-Communist Ukraine. Problems of Post-Communism, 58(6): 3-20.

Seceleanu, A. (2009). Mediatization of political life in conditions of electoral campaign-a retrospection of the elections in Romania, Central European Journal of Communication, 2(03): 267-278.

Shannon, C. (1948) A Mathematical Theory of Communication. Bell System Technical Journal.

Shveda, Y., \& Park, J. H. (2016). Ukraine's Revolution of Dignity: The Dynamics of Euromaidan. Journal of Eurasian Studies, 7(1): 85-91.

Snowball (2021). Snowball Introduction. Snowball. Retrieved March 1, 2021 from https://snowballstem.org/. Spirova, M. (2008). The "Color Revolutions" in Georgia and Ukraine. Taiwan Journal of Democracy, 4(2): 75-90.

Szostek, J. (2014). Russia and the News Media in Ukraine: A Case of "Soft Power"? East European Politics and Societies: And Cultures, 28(3): 463-486.

TSN.ua (2019, April 1). Vipusk TSN. Vibir Krayini Za 31 Bereznya 2019 Roku (Povna Versiya Ch.1) [Release of TSN. Choice of the Country for March 31, 2019 (Full Version P.1)]. TSN.ua. Retrieved February 17, 2021 from https://tsn.ua/video/video-novini/vipusk-tsn-vibir-krayini-za-31-bereznya-2019-roku-povna-versiya-ch-1.html.

Tversky, A., \& Kahneman, D. (1981). The Framing of Decisions and the Psychology of Choice. Science, 211(4481): 453-458. 
Verkhovna Rada of Ukraine (2020). The Constitution of Ukraine. Verkhovna Rada of Ukraine. Retrieved March 4, 2021 from https://zakon.rada.gov.ua/laws/show/254к/96-вp?lang=en\#Text.

Yau, C. K., Porter, A., Newman, N., \& Suominen, A. (2014). Clustering scientific documents with topic modeling. Scientometrics, 100(3): 1-19. 